\title{
Effect of volcanic ash over Orthoptera survival in Patagonia
}

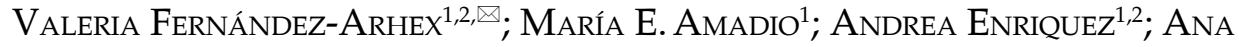 \\ Pietrantuono $^{1,2}$; Guillermo Becker ${ }^{1}$ \& Octavio Bruzzone ${ }^{1,2}$
}

1. Instituto Nacional de Tecnología Agropecuaria, Estación Experimental Agropecuaria Bariloche, Argentina. 2. CONICET

\begin{abstract}
Aвstract. The aim of this work was to evaluate the ash toxicity from the Puyehue-Cordón Caulle volcanic complex on the survival of two Orthopteran species: the grasshoper Dichroplus vittigerum and the green locust Brugilis sp. Two grain size were used to evaluate the effect of volcanic eruption on these insects. Chemical analyses from this eruption proved that the ashes were very abrasive and predominantly composed of silica shards $\left(\mathrm{SiO}_{2}\right)$ and aluminia $\left(\mathrm{Al}_{2} \mathrm{O}_{3}\right)$, two substances with insecticidal properties. In northern Patagonia, both orthopteran species are polyphagous chewers on grasses and dicots. The laboratory data showed that sustained exposure to volcanic ash induced mortality in adult grasshoppers. Survival of D. vittigerum significantly decreased once exposed to the two ash granulometries. In turn, Brugilis sp. survival was significantly reduced when exposed to fine grain ashes. These results suggest that the onset of the volcanic eruption with the consequent suspension of the pyroclastic material in the air might negatively impacted these orthopteran due to the mortality of adults. The ash from the Puyehue-Cordón Caulle volcanic complex could be compared to the application of non-persistent and broad spectrum insecticide, causing a temporary reduction in orthopteran populations.
\end{abstract}

[Keywords: grasshoppers, inert dust, locusts, Patagonia, survival]

Resumen. Efecto de la ceniza volcánica sobre la supervivencia de ortópteros en la Patagonia: El objetivo de este trabajo fue evaluar la toxicidad de las cenizas volcánicas del volcán Puyehue-cordón Caulle en la supervivencia de dos especies de Orthoptera: la tucura Dichroplus vittigerum y la langosta verde Brugilis sp. Se utilizaron dos granulometrías de ceniza para evaluar el efecto de las erupciones volcánicas sobre estos insectos. El análisis químico de la ceniza de esta erupción demostró que estas fueron muy abrasivas y estuvieron predominantemente compuestas por fragmentos de sílice $\left(\mathrm{SiO}_{2}\right)$ y alúmina $\left(\mathrm{Al}_{2} \mathrm{O}_{3}\right)$, dos sustancias con propiedades insecticidas. En el norte de la Patagonia, ambas especies de ortópteros son polífagas, masticadoras de pastos y dicotiledóneas. Los datos de laboratorio mostraron que la exposición sostenida a la ceniza volcánica provocó mortalidad en adultos de ambas especies. La supervivencia de $D$. vittigerum disminuyó significativamente bajo las dos granulometrías. La supervivencia de Brugilis sp. se redujo significativamente ante la ceniza fina. Estos resultados sugieren que la erupción volcánica, con la consiguiente suspensión del material piroclástico en el aire, pudo haber impactado negativamente sobre las poblaciones de ortópteros mediante la mortalidad de adultos. La ceniza del complejo volcánico Puyehue-Caulle se podría comparar con la aplicación de un insecticida de amplio espectro no persistente, causando una reducción temporal en poblaciones de ortópteros.

[Palabras clave: langostas, Patagonia, polvos inertes, supervivencia, tucuras]

\section{INTRODUCTION}

Natural catastrophic events such as volcano eruptions have greatly affected environments in wide regions around the world (Elizalde 2014; Fernández-Arhex et al., in press). The general consequences of this type of event are loss of habitats for flora and fauna, and decrease of susceptible insect populations due to the insecticidal effect of the ashes (Akre 1980; 1981; Shanks \& Chase 1981; Buteler et al. 2011; Fernández-Arhex et al. 2013). Indeed, insect populations are affected by the area covered by the ash plume, duration of the exposure to volcanic ash, and chemical composition of the pyroclastic material. These events cause different impacts according to the taxa and the stage of insects (Shanks \& Chase 1981; Akre

fernandezarhex.v@inta.gob.ar et al. 1981; Brown \& Hussain 1981; Martinez et al. 2013; Masciocchi et al. 2013; Pirk 2014; Morales et al. 2014; Fernández-Arhex et al., in press; Pietrantuono et al. 2014).

In June 2011, the eruption of the PuyehueCordón Caulle (PC) volcanic complex in Chile deposited large amounts of volcanic ash over Patagonia. This volcanic complex dispersed about 100 million metric tons of ash over 7.5 million hectares mainly in northern Patagonia (Argentina) (Gaitán et al. 2011). The magnitude of this eruption was so important that affected distant places, mainly in northern Patagonia (i.e. Río Negro and Neuquén). The volcanic material was dispersed by wind in west-east direction transporting different ash grain sizes. In places close to the volcano the 
ash particles size were thicker, while in distant places ash particles were finer. The chemical analyses of the volcanic ash showed that is extremely abrasive (Informe UNCO-Neuquén 2011) and predominantly composed of glass shards $\left(\mathrm{SiO}_{2}\right)$ and aluminia $\left(\mathrm{Al}_{2} \mathrm{O}_{3}\right)$ (Buteler et al. 2011; Mogni et al. 2011), two substances with insecticidal properties (Shanks \& Chase 1981; Subramanyam \& Roesli 2000).

The mechanism of action of these insecticides is through the abrasion and adsorption of the epicuticular waxes phenomena, leading to insect's desiccation. Occlusion of spiracles, excessive salivation activity, cleanliness and the interruption of digestive activity by the accumulation of ash in the intestine are contributing factors (Wigglesworth 1944; Wille \& Fuentes 1975; Edwards \& Schwertz 1981; Stadler et al. 2010).

Several species of rangeland grasshoppers and green locusts (Orthoptera: Acrididae) are considered pests for plants (Ibrahim 1983; Latchininsky et al. 2007). Often, these insects compete with livestock and wildlife for grazing resources (Fielding \& Brusven 1995). In northern Patagonia, South America, the native grasshopper Dichroplus vittigerum (Blanchard), and the migratory green locust Brugilis sp. (Krauss) are polyphagous chewers of grasses and dicots. As these species affect natural grasslands, the main forage source for extensive livestock (de Wysiecki \& Sánchez 1992), they are potential pests for the region. Besides, many authors predict that climate change will have a number of effects on insects: sweeping shifts in herbivory rates, altered distribution and outbreak frequency of key insect pests, and unpredictably altered relationships with natural enemies (Williams \& Liebhold 1995; Fleming 1996; Coley 1998; Tenow et al. 1999). Therefore, underestanding the dynamics of this pest species is relevant for the development of future management strategies.

Because the ash plume affects the natural distribution of these insects, we investigated if grain size of volcanic ash differentially affects the survival of two orthopteran species, $D$. vittigerum and Brugilis sp.

\section{Methods}

Adult females of $D$. vittigerum were collected from

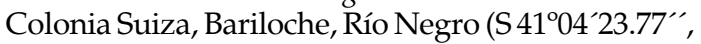
W 71'32'14.41"') and Brugilis sp. were collected from Fernández Oro, Río Negro (S 355656.25”, W $67^{\circ} 54^{\prime 3} 30.78^{\prime \prime}$ ) Argentina. The individuals were transported to the laboratory to study the effect of volcanic ash over their survival (measured as survival probability per day).

Five to six individuals were introduced in a $15 \times 30$ $\times 8 \mathrm{~cm}$ plastic container with food and volcanic ash (treatment) or food without volcanic ash (control). We fed them with fresh leaves of Taraxacum officinale F.H. Wigg (Asterales: Asteraceae) ad libitum. The leaves were daily renewed. This forb is widely distributed in meadows from the area affected by the volcano. Insects were grouped since they had enough food to prevent cannibalism (pers. obs.). A total of five containers were used as it follows: (1) Grasshopper Control; (2) Grasshopper under fine grain size; (3) Grasshopper under thick grain size; (4) Locust Control; (5) Locust under fine grain size. Each treatment was replicated four times. After each replicate the containers were washed and ventilated to avoid pseudo-replication (Ramirez et al. 2000).

To evaluate the ash effect according to wind conditions of the rangeland affected by the PC eruption (mean wind speed in the region is $7 \mathrm{~km} /$ h), a fan was set on top of the plastic containers. It was turned on four times a day for one hour. Temperature and humidity were controlled and established according to Fernández-Arhex et al. (2013) $\left(20.43^{\circ} \mathrm{C} \pm 0.01,39.57 \pm 0.09 \% \mathrm{RH}\right)$. The experiment begun when the insects were exposed to simulated wind and $15 \mathrm{~g}$ of volcanic ash collected from Ing. Jacobacci, Río Negro (S 41ํ 18' 0", O $69^{\circ}$ $35^{\prime} 0$ "; the entire container floor was covered with ash).

In the case of grasshoppers, they were exposed to two grain particle sizes $(n=20$, fine $<500$; $n=$ 28 , medium $=500 \mu \mathrm{m}$ and $n=22$ control), while for green locusts, they were exposed only to fine grain size $(n=18$, fine grain and $n=20$ control; because there were few individuals in the field to capture). Mortality was daily recorded. Data analyses were carried out using Log-Rank test for survival analysis. Significantly different least square means $(\mathrm{P}<0.05)$ were performed with the Holm-Sidak method $(\mathrm{P}<0.05)$ using the Sigma Stat 3.5 statistical package designed by STATCON@ Witzenhausen, Germany.

\section{RESULTS}

Survival of grasshoppers and green locusts were significantly reduced by exposure to volcanic ash. Under ashless conditions grasshoppers lived $17 \pm 1.84$ (median \pm SE) days and locust lived $17 \pm 4.02$ (median \pm $\mathrm{SE}$ ) days. In the case of $D$. vittigerum, their survival significantly decreased when they were exposed to both ash granulometries (Log-Rank test $=35.86, \mathrm{df}=2, P<0.001 ;$ Holm 

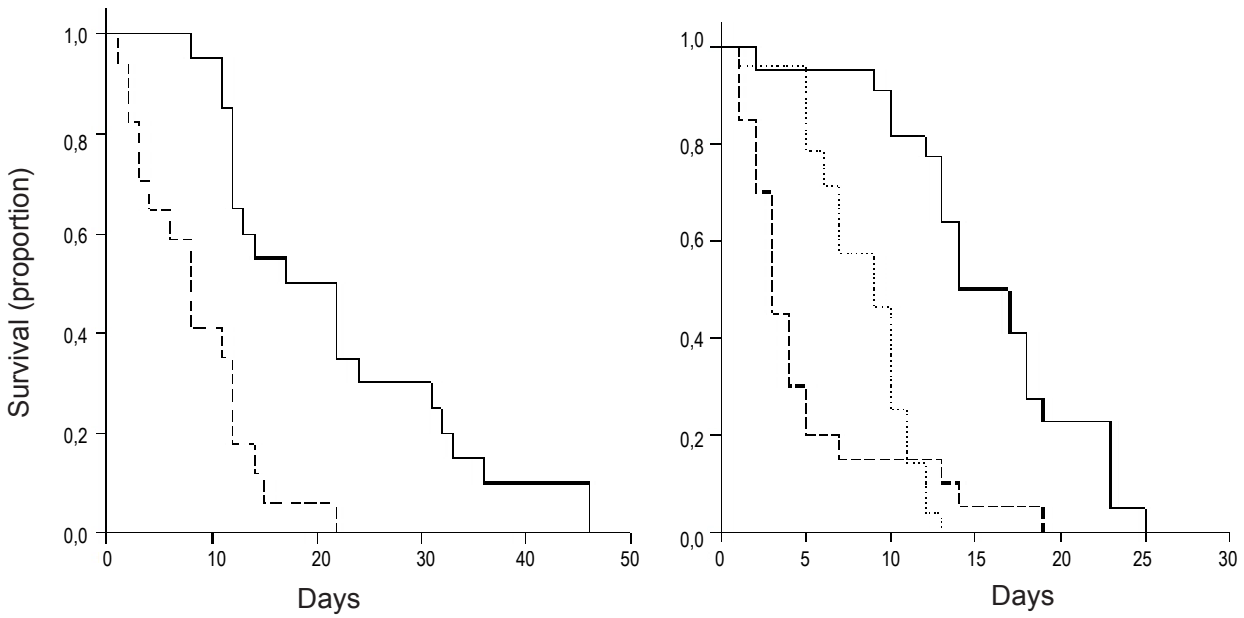

Figure 1. a, b. Survival times (days) of (a) Dichroplus vittigerum and (b) Burgilis sp. placed in plastic cages with or without volcanic ash (control) and fed with fresh leaves of dandelion (Taraxacum officinale) ad libitum. A fan was used to simulate wind gusts. D. vittigerum: Log-Rank test; Statistic 35.86; $\mathrm{df}=2 ; P<0.001$. Holm Sidak Test applied to the data: control vs. medium volcanic ash $(500 \mu \mathrm{m}) P=0.017$; control vs. fine volcanic ash $(<500 \mu \mathrm{m}) P=0.02$. Burgilis sp.: Log-Rank test; Statistic 16.42; $\mathrm{df}=1 ; P<0.001$. A fan was used to simulate wind gusts. Control (-), Medium ash (...), Fine ash (--).

Figura 1. a, b. Tiempo de supervivencia (días) de (a) Dichroplus vittigerum y (b) Burgilis sp., colocados en jaulas de plástico con o sin (control) ceniza volcánica, alimentados ad libitum con hojas frescas de diente de león (Taraxacum officinale). Se utilizó un ventilador para simular ráfagas de viento. Ver detalles en leyenda en inglés.

Sidak Test: control vs. fine volcanic ash, $P$ $=0.02$; control vs. medium volcanic ash, $P$ $=0.017$ ) (Figure 1a). D. vittigerum survival decreased on average to $3 \pm 0.56$ (median \pm SE) days with fine ash, and $9 \pm 0.88$ (median \pm SE) days with medium size ash. In turn, Brugilis sp. survival was significantly reduced when exposed to fine ash (Log-Rank test; Statistic 16.42; $\mathrm{df}=1 ; \mathrm{P}<0.001$ ) (Figure $1 \mathrm{~b}$ ). Survival was reduced on average to $8 \pm 1.35$ (median \pm SE) days when exposed to fine ash.

\section{DISCUSSION}

Ash treatments increased the mortality of grasshopper and green locust species, regardless of the grain size. The lower survival could be due to the abrasive exposure of this ash suspended in the air, causing desiccation of the insects. Ash may also cause occlusion of spiracles, salivation, excessive grooming activity and ash accumulation in the digestive system with consequent death (see Buteler et al. 2011, 2014). Shanks and Chase (1981) demonstrated the effect of ash in weevils. The constant walking and feeding on ashes produced the insertion of ash particles into membrane areas between the mouthparts and appendages, where tissue is susceptible to be damaged. For this reason, they stated that these insects lose their abilities to feed, and finally die of desiccation. Also, in honeybees (Apis mellifera) the volcanic ash of
PC reduces its survival, indicating that there is no mechanism to prevent ingestion of food contaminated with ash (Martínez et al. 2013). In the case of invasive wasp Vespula spp., their populations were severely affected by the ash deposition and plume, caused by the eruption of the volcano. Populations of this wasp were completely devastated in areas where ash thickness was $>3 \mathrm{~cm}$ (Masciocchi et al. 2013). On the other hand, Morales et al. (2014) studied the impact of the ash in the foraging behavior of bees. They evaluated the effect of the gradient of increasing ash layer thickness on wild bees, native (Bombus dahlbomii) and invasive (B. terrestris and $B$. ruderatus) bumble bees. They found, with the increase of ash deposition, a consistent and significant decrease in: the number of wild bees and total bee richness visiting raspberry flowers; the number of bumble bees (particularly B. terrestris) visiting wild flowers; and the proportion of triggered flowers of scotch broom. Thus, volcanic eruptions of PC can exert a detrimental effect on bee fauna.

Our results, in addition to those obtained by Fernández-Arhex etal. (2013), may suggest that the survival of grasshopper and green locust adults could be affected by a combination of factors like climatic conditions during the initial ash fall, dispersal of the ash by wind and suspended volcanic ash, regardless of particle size. A volcanic eruption causes 
changes in the environment, Chaneton et al. (2014) argued that ash fall on distant forest canopies and soils may disrupt species interactions and ecosystem level processes like primary productivity and herbivory (Bishop et al. 2005, Marske et al. 2007). They considered that the effects from ash fall varied with site distance to the crater (see also Dale et al. 2005). Thus herbivorous searching behavior could be affected. Consequently, the possible impact of the volcanic ash is not the same for all insect species, depending mainly on their habits, behavior, motivation and life cycle (Marske et al. 2007; Pietrantuono et al. 2014).

In this work, we may assume that the ashes will have a long term effect on the insects' survival. This may occur because when the ashes fell, on June 2011, the eggs of the evaluated insects were located underground, fully protected of ash effect; as a consequence the populations from the area affected with the volcanic ash would be negatively influenced in the following seasons. In these seasons the nymphs and adults will emerge in an environment contaminated with ash, together with the prevailing conditions of wind and warm weather from the region, so that the volcanic ash will have a negative effect on insects due to its abrasive and desiccant action.

Fernández-Arhex et al. (2013) had shown that the toxicity of this volcanic ash has an insecticidal effect similar to that of diatomaceous earth (an inert dust with insecticidal properties). Suggesting that volcanic ash could be use as a natural insecticide. Therefore, this ash may be compared to the application of non-persistent and broad spectrum natural insecticide as well as it can be used in integrated pest management strategies. Further studies are needed to understand the effect of this volcanic ash on these insects population in the field. It is also necessary to evaluate the effectiveness of volcanic ash as an indoors insecticide such as in greenhouses.

Acknowledgments: We thank C Gittins and P Lagorio for discussing our work at different developmental stages. This work was financed by grant PROEVO 2011-40-B-185, PICT 2508 and PIP 11220100100266.

\section{REFERENCES}

AKRE, RD. 1980. Effect of volcanic ash on insects. Wash. State Univ. Conf. Aftermatch of St. Helens. July 8-9. Pp. 14-15.
AKRE, RD; Ld HANSEn; HC REEd \& LD CoRpus. 1981. Effects of volcanic ash from Mt. St. Helens on ants and yellow jackets. Melanderia, 37:1-19.

Bishop, JG; WF William; JD Schade \& CM CRISAFulli. 2005. Causes and consequences of herbivory on prairie lupine (Lupinus lepidus) in early primary succession, Pp. 151162, In: Dale, VH; FJ Swanson \& CM Crisafulli (eds.). Ecological Responses to the 1980 Eruption of Mount St. Helens. Springer, New York.

Brown, JJ \& Y Hussain. 1981. Physiological effects of volcanic ash upon selected insects [including honeybees] in the laboratory. Melanderia, 37:30-38.

Buteler, M; T Stadler; GP López García; MS Lassa; D Trombotto Liaudat; P D'Adamo \& V Fernández-arhex. 2011. Propiedades insecticidas de la ceniza del complejo volcánico Puyehue-Cordón Caulle y su posible impacto ambiental. Rev. Soc. Entomol. Arg., 70:149-156.

Buteler M, GP López García, AA Pochettino, N Stefanazzi, AA FERRERO \& T STADLER. 2014. Insecticidal activity of volcanic ash against Sitophilus oryzae L. (Coleoptera: Curculionidae) under laboratory conditions. Ecol. Aust., 24:17-22.

Chaneton EJ, N Mazía, LA Garibaldi, J Chaij \& T KitZBERGER. 2014. Impact of volcanic ash deposition on foliar productivity and insect herbivory in northern Patagonia deciduous forests. Ecol. Aust., 24:51-63.

Coley, PD. 1998. Possible effects of climate change on plant/herbivore interactions in moist tropical forests. Climatic Change, 39:455-472.

Dale, VH; FJ Swanson \& CM CRisafulli. Eds. 2005. Ecological Responses to the 1980 Eruption of Mount St. Helens. Springer, New York.

De WYSIECKI, ML \& NE SÁNCHEZ. 1992. Dieta y remoción del forraje de Dichroplus pratensis (Orthoptera, Acrididae) en un pastizal natural de la provincia de La Pampa, Argentina. Ecol. Aust., 2:19-27.

EdWARDS, JS \& LM Schwertz. 1981. Mount St. Helens ash: a natural insecticide. Can. J. Zool., 59:714-715.

ElizALDE, L. 2014. Volcanism and arthropods: a review. Ecol. Aust., 24:3-16.

Fernández-Arhex V; M Buteler; ME Amadio; A EnriqueZ; AL Pietrantuono; T Stadler; G Becker \& O Bruzzone. 2013. The effects of volcanic ash from puyehue-caulle range eruption on the survival of Dichroplus vittigerum (Orthoptera: Acrididae). Fla. Entomol., 96(1): 286-288.

Fernández-Arhex V; A L Pietrantuono; M E Amadio \& O Bruzzone. Volcanic complex Puyehue-Cordón Caulle: impact of volcanic ash on insects in Patagonia, Argentina. In: Volcanic Eruptions: Triggers, Role of Climate Change and Environmental Effects. In press

Fielding, DJ \& MA BRUsven. 1995. Ecological correlates between rangeland grasshopper (Orthoptera: Acrididae) and plant communities of southern Idaho. Environm. Entomol., 24:1432-1441.

FLEMING, RA. 1996. A mechanistic perspective of possible influences of climate change on defoliating insects in North America's boreal forests. Silva Fenn, 30:281-294.

Gaitán, JJ; F RafFo; JA Ayesa; F Umaña \& DB Bran. 2011. Zonificación del área afectada por cenizas volcánicas. INTA EEA Bariloche "Dr. Greenville Morris", Ministerio de Agricultura, Ganadería y Pesca de la Nación. Bariloche. http://inta.gob.ar/documentos/ zonificacion-del-area-afectada-por-cenizas-volcanicasen-rio-negro-y-neuquen/[Accesed 26 August 2013].

IBRAHIM, MM. 1983. On the morphology and biology of the 
immature stages of the grasshopper Heteracris littoralis Rambur (Orthoptera: Acrididae). College Sci. King Saud Univ., 14:63-73.

Informe de los laboratorios de la Facultad de Ingeniería, Departamentos de Geología y Petróleo (CIMARCPEM) y Departamento de Química. 2011. Análisis y caracterización de cenizas procedentes del Complejo Volcánico Puyehue - Cordón Caulle depositadas en la ciudad de Neuquén y Alto Valle del Río Negro. Univ. Nac. Comahue, Neuquén. 6 pp.

LATCHININSKY, AV; R SiVANPILLAI; KL DRIESE \& H WILPS. 2007. Can early season Landsat images improve locust habitat monitoring in the Amudarya River Delta of Uzbekistan. J. Orthop. Res., 16:167-173.

MartíneZ, AS; M Masciocchi; JM Villacide; G Huerta; L Daneri; A BruchHausen; G Rozas \& JC Corley. 2013. Ashes in the air: the effects of volcanic ash emissions on plant-pollinator relationships and possible consequences for apiculture. Apidologie, 44: 268-277.

MarsKe, KA; MA Ivie \& GM Hilton. 2007. Effects of volcanic ash on the forest canopy insects of Montserrat, West Indies. Environ. Entomol., 36:817-25.

Masciocchi, M; AJ Pereira; MV Lantschner \& JC CORLEY. 2013. Of volcanoes and insects: the impact of the Puyehue-Cordon Caulle ash fall on populations of invasive social wasps, Vespula spp. Ecol. Res., 28: 268-277.

Mogni, L; C Cotaro \& R Daga. 2011. Análisis preliminar cenizas volcánicas sistema Puyehue-Cordón Caulle - 0406-11. http://organismos.chubut.gov.ar/ambiente / files / 2011/06/Informe-Cenizas-Puyehue1.CAB_.pdf.

Morales Cl, A Saez, MP Arbetman, L Cavallero \& MA AIzEN. 2014. Detrimental effects of volcanic ash deposition on bee fauna and plant-pollinator interactions. Ecol. Aust., 24:42-50.
Pietrantuono, AL; V Fernández- Arhex \& OA Bruzzone. 2014. First study of host-plant preferences of Sinopla perpunctatus (Hemiptera: Acanthosomatidae) a stink bug from the Andean- Patagonic forest. Fla. Entomol., 97:534-539.

PIRK, G. 2014. Did ash fall from Puyehue-Cordón Caulle volcanic complex affect ant abundance and richness in the Patagonian steppe?. Ecol. Aust., 24:23-30.

Ramirez, CC; E Fuentes-Contreras; LC Rodriguez \& HM NiEMEYer. 2000. Pseudoreplication and its frequency in olfactometric laboratory studies. J. Chem. Ecol., 26: 142-143.

SHANKS, CH Jr \& DL CHASE. 1981. Effect of volcanic ash on adult Otiorhynchus (Coleoptera: Curculionidae). Melanderia, 37: 63-66.

STADLER, T;MBUteler \&DKWEAVER. 2010. Nanoinsecticidas: Nuevas perspectivas para el control de plagas. Rev. Soc. Entomol. Argentina, 69:149-156.

Subramanyam, B \& R RoesLi. 2000. Inert dusts, Pp. 321-379, In: B Subramanyam \& DW Hagstrum (eds.), Alternatives to Pesticides in stored-product IMP. Kluwer Academic Publishers, Boston, Massachusetts.

Tenow, O; AC Nilssen; B Holmgren \& F Elverum. 1999. An insect (Argyresthia retinella, Lep., Yponomeutidae) outbreak in northern birch forests, released by climatic changes? J. Appl. Ecol., 36:111-122.

WigGLESWORTH, VB. 1944. Action of inert dusts on insects. Nature, 153:493-494.

WILLE, A \& G Fuentes. 1975. Efecto de la ceniza del volcán Irazú (Costa Rica) en algunos insectos. Rev. Biol. Trop., 23:165-175.

WilLIAMS, DW \& M LieBHOLD. 1995. Herbivorous insects and global change: potential changes in the spatial distribution of forest defoliators. J. Biogeogr., 22:665-671. 